\title{
Demystifying Misted Mirrors to Investigate Emerging People Issues in SMEs: Implications for Strategic Change
}

\section{Forthcoming in Special Issue on Organisation Design Products in Strategic Change Journal - January 2020}

\author{
Dr John Mendy
}

Lincoln International Business School

University of Lincoln

LN6 7TS

\section{Email: jmendy@lincoln.ac.uk}

\begin{abstract}
Although 'mirroring' has been studied within MNEs, the way SMEs deal with the challenges associated with implementing new products and services in change contexts remains a neglected area. By subsuming mirroring and change management theories under organisational theory, the author examines the impacts of these constructs on how four SMEs dealt with some of their challenges as they tried to launch new products, improve services and staff performance. The paper contributes to the organisation theory and strategy literature by initially identifying 'organisations design products' as a gap whose linkage to HRM architectural pairings produced the theoretical contribution referred to as 'Contingent Misting'. The theory helps in identifying the structural, cultural and technical characteristics that SMEs are dealing with and deepens our understanding of some of the emerging mirroring architectures that SMEs face. A thematic categorisation approach to the analysis of the interview data led not only to the paper's theoretical contribution of 'Contingent Misting' but also highlights individual and organisational-level characteristics whose combination help SMEs to better adapt to the complex challenges of product and service redesigns. The paper's 85 semi-structured interviews in $4 \mathrm{UK} /$ internationally-connected SMEs was used to successfully frame SMEs' products, services, structures and people in a theory that highlights the contingent nature of people's competence when SMEs implement changes to practically tackle their challenges. 'Contingent Misting' was previously missing in the architectural pairings and mirroring literature and is therefore proposed as the paper's theoretical contribution. Its benefits, implications and future research directions are identified.
\end{abstract}

KEYWORDS: products, organisation, mirroring, misting, contingency, competence, change 


\section{INTRODUCTION}

SMEs' positive impacts on 'national economies' have caught the attention of researchers (Steinerowska-Streb and Steiner, 2014, p. 375; Gunasekaran, Rai and Griffin, 2011). Despite their contributions to market growth and entrepreneurship activities, the way SMEs deal with the complex processes of managing constraints related to adaptation ((Williams et al., 2014; Simon, 1962) are under-researched. On the other hand, there has been a plethora of research on product designs (MacCormack, Verganti and Iansiti, 2001; Sanderson and Uzumeri, 1995), on manufacturing (Ulrich, 1995) and on improving to the structures and technologies (Spear and Bowen, 1999) that might enhance product designs in predominantly MNEs (Baldwin and Clark, 2000). However, there is a dearth of empirical research on product designs and the effectiveness of the impact of architectural pairings on new products and services (Fleming and Sorenson, 2004) in MNEs and SMEs alike. The construct of 'mirroring' has been proposed by scholars such as MacCormack, Baldwin and Rusnak (2012) to highlight the interaction between an organisation's structure and its products' design. 'Mirroring' has been conceptualised as the way an organisation's management, decisionmaking and communication practices and systems shape and are shaped by its products. Some companies have adopted this new architectural way of pairing products and organisations with the hope that positive results would be achieved. Although this has been claimed to have efficient results in MNEs (Elia et al., 2017), the application of 'mirroring' on new products and services has received neglect in SMEs.

Despite this glaring gap, there also seems to be limited investigations into SME contexts and in the way they manage the possible mirroring impacts on individual and collective outcomes. What is encouraging to note is the growing recognition of how management may use 'mirroring' as a technique to deal with some innovation challenges and complexity (Tassabehji and Isherwood, 2014) in a product's lifecycle (Garezzi et al., 2005). However, there is a problem which can be explained by the fact that studies that emphasise on 'mirroring' as a technique appear to focus on an apparent binary-divide: conceptual/normative or descriptive. The concept polarises the debates and discussions further. Complex people and systems issues related to product changes remain unresolved despite the efforts made by Simon (1962) and his colleagues. Macro-economic constraints (Kola and Kodongo, 2017), product export growth issues (Quaicoe et al., 2017) and product architecture and management constraints have added to the limited success of the technique, 
as a strategic tool (Ulrich, 1995). Other researchers proposed product performance and management (Liu and Vrontis, 2017) as a strategy (Zoogah and Mburu, 2015) that targets modular aspects related to SMEs' internationalisation (Saridakis et al., 2017).

Other aspects related to the modular view of mirroring include transformational leadership (Top et al., 2015) and the standardisation of HRM practices to help manage product development (Ulrich, 1995). More recent developments to product and service design organisations (Budhwar et al., 2017; Edmondson and Harvey, 2017; Jimenez et al., 2017; Goerzen, 2017) have pointed to the incomplete narrative in highlighting the way SMEs deal with the complex constraints related to how people adapt on a higher level (Lwango et al., 2017). North (1990), Scott (1995) and Peng et al.'s (2008) institutional theory provided earlier, useful additions to the normative stream of strategic product/service design organisations. However, they overlooked the way people choose to surmount the higher-level organisational barriers that might clash with their objectives (Estrin et al., 2017; Muellner et al., 2017). The proposals examined thus far raise an important research question for this paper: 'is there a theoretical contribution that might be developed to fill the gap in the strategy literature on mirroring as a management technique for product and service change?' The question has received a number of answers previously (Lewin, 1947) although its overall neglect in SMEs' adaptation strategy signals that some different theoretical proposition is nigh.

The results of a study of how SMEs and employees were able to help their companies innovate and thereby respond to the research question posed here provide an inkling to an answer (Mendy, 2017). Earlier Porter and Kramer (2011) adopted techniques considered as 'narrow' given their limited focus on macro-organisational objectives as these only serve management's and the organisation's intentions. As such, they failed to enhance staff competence. The methodology involved was a survey of management and non-management staff, which was used as the empirical basis to validate the author's theoretical contribution. Its fundamental objective can be situated in highlighting some concept which identifies the characteristics needed by people caught in similar situations to develop some competency of how to innovate during products and service quality change. The characteristics needed for such capacity are referred to in the concept of 'Contingent Mirroring'. It especially highlights the capability required if staff and organisations in similar contexts stand a possibility of realising their organisation-product pairing combinations. It also signals the people 
behaviours that can bring about more positive organisational pairings than previously attempted in the mirroring literature. Such outcomes have been found to be dependent or contingently based on people's perceptions of what is required to deal with the product and service quality related challenges in the here and now. Earlier contributions of whether 'mirroring' techniques (Baldwin and Clark, 2000) could be beneficial to the strategy (Ulrich and Dulebohn, 2015) of SMEs remain scantily investigated.

\section{LITERATURE REVIEW}

'Mirroring' has been used in the literature to examine constraints faced by organisations that attempt to innovate (Colfer and Baldwin, 2016). The construct highlights the way organisations examine tasks/jobs, people and their performance and the structuring of systems and hierarchies needed to optimise outcomes. Institutional theorists such as Scott (1995) and North (1990) have postulated that strategic choices are needed to resolve the complexities involved in task, product and service designs. They recommend the use of formal and informal systems in product redesign. Appealing as this may sound to scholars and practitioners (Peters, 2011; Campbell, 2007) organisations are still reeling from complex problems related to people performance, product growth and service improvements thereby prompting others to propose a Universal HRM model (Brewster, 1999; Huselid, 1995). Its focus is on improving an organisation's internal operations (Pfeffer, 1995) so as to realise the benefits posited by MacCormack, Baldwin and Rusnak (2012). When this has not worked, the notion of 'fit' or congruence between proposed HRM practices and mechanisms such as recruitment, selection, appraisals and so on were used to show the impacts that their application could have on businesses (Ichniowski et al., 1997; Huselid et al., 1997). However, Moon et al. (2011) highlight that structural, modular 'fit' is not enough. Other scholars note that managerial 'core competence' is also needed to sustain the value of products and services (see Simon, 1962; Colfer and Baldwin; 2016). The limitation of management input has led to calls to investigate the contribution of other change agents (Bouckenooghe, 2010), their objectives (Lenseges et al., 2016) to ascertain whether 'mirroring' techniques (McGregor, 1960) could benefit from some extension.

Attempts for such extension have been noted in Weick's (1976) notion of complexity which recognises the interplay between structures and anticipated product efficiency (Gokpinar et al., 2007; Conway, 1968). Other scholars observe that processes involved in product 
redesigns should be prioritised (MacCormack et al., 2001). Some scholars are analytical (MacCormack et al., 2006) whilst others describe the processes involved (Sosa et al., 2007). Despite the binary divide, some seminal literatures have observed the way modular aspects of a company's products and services are integrated or decoupled from the organisational structures and systems (Orton and Weick, 1990). Ulrich (1995) tried to escape the binary categorisation by simply labelling what he found as 'loose-coupling'. Despite the propositions, there appears to be a 'wickedness' (Rittel and Weber, 1973) about mirroring which highlights that its issues need urgent attention

A crucial issue is to do with the recurrence of complexity problems/challenges during change. It is thought that innovation might help in decision-making, choice-availability and knowledge-sharing as a way to enhance open innovation and competitive advantage (Chesbrough, 2003; MacCormack et al., 2007). Others have proposed aligning modular components of a business (for example, communication, appraisals, product design) and product sales, performance, customer-satisfaction levels and so on (Sosa et al., 2004). Reported cases of misalignment still abound (Gokpinar et al., 2007) thereby disrupting the efficient functioning of a product and raising further questions whether its technical and technological properties were initially properly 'mirrored' to performance. Although there is a view that 'misalignment' between products, services and outcomes could happen (Henderson and Clark, 1990) the way modular and leadership structures are organised ought to 'mirror' communication, product and other organisation-specific outcomes (Conway, 1968). Despite the proposed maintenance of stable structures to achieve the intended outcomes risks related to knowledge generation and communication exist (Utterback, 1994).

Another issue is to do with mitigating against the risks involved when a new wave of knowledge, new products, techniques and processes (Brusoni et al., 2001) and organisational designs are being proposed (Nonaka, 1994). However, such efforts are met with ever-more complex problems (Simon, 1962) and architectural changes (Baldwin and Clark, 2000). Therefore, a different way of coordination of the complex organisational and people functions (both 'old' and 'new') is also required (Galbraith, 1974). Coordination the different people-related aspects such as task allocation, employee selection, training and feedback loops expose the emerging dynamics between an organisation's internal and external, operating environment (Tushman and Nadler, 1978). 
Dealing with the risks has not deterred the literature from highlighting that using an organisation's mechanisms and designs might not lead to the achievement of the anticipated outcomes whether it adopts a one-way or dual-environmental relationship (Fixson and Park, 2008) (also see Conway's 1968 Law). Part of the problem is highlighted in the Law that products are interdependent photocopies (Puranam et al., 2012) of the internal organisational structures and mechanisms (i.e. coordination, communication, selection and management of staff and so on). Part of the explanation for this is that organisational structures (Chandler, 1977) and contexts differ and different forms of modularity (integration and disintegration) and problem-solving capacities abound in a diversity of organisation types and architectural designs. The notion of 'modularity' is therefore used to highlight the way different aspects of an issue are structurally decomposed and resolved (Simon, 1962) although Nickerson and Zenger (2004) perceive differently. It is argued that perceiving organisational design issues as opportunities could help to render effective and efficient task or service delivery (Thompson, 1967) once the constituent aspects are efficiently targeted (Alexander, 1964). This is thought to enhance knowledge generation (Baldwin and Clark, 2000). Such analysis appears to highlight that architectural pairings need technological and technical support if their implementation is to be successful (Crawley et al., 2004). However, challenges such as hierarchical miscommunication, misaligned coordination of the different aspects might render the organisation's boundaries unclear (Langlois, 2002) thereby leading to 'misting' (Furlan et al., 2013). The construct is generally defined as when relationships between different components within modular structures are ambiguous leading to sub or even non-optimal functional efficiency.

The attendant limitations in the earlier construct of 'mirroring' has led the author to select and discuss another key construct in product and service redesign which is 'misting' to see what can be contributed. Its proponents explain what might account for this 'mist'. They highlight that it could emanate from within a company's operations in the way these might be 'misaligned' or 'loosely-coupled' to modular architectural pairings (Orton and Weick, 1990). The remaining part of the analysis for such mismatch is that a firm's external operating environment could render the relationships between the technical, structural components so dynamic that organisations could disintegrate when challenged by innovation (Wolter and Veloso, 2008) and a need to share knowledge (Baldwin and Clark, 2000). Although different types of changes to the organisational-product-architectural pairings (Baldwin, 2015) recommend 'modularity' as an approach (MacDuffie, 2013) the full story has not been told. 
Despite the recognition of a macro, external operating environment which has ushered in the open systems perspective of managing turbulence (Scott, 1981) (re)configuring the emerging constraints further mystifies whether organisations should adopt mirroring, misting or remain as open systems (Lawrence and Lorsch, 1967). HRM scholars have proposed 'High Performance Work Practices' (HPWPs) (Becker and Huselid, 2006) as part of a strategy to boost firm performance and output (Kaufman, 2015) and product profitability (Van Wanrooy et al., 2013) in line with organisational structure types (Gerhart and Fang, 2014) and employee-employer objectives (Marsden and Dickinson, 2010). However, different employment types (Jimenez et al., 2017; Goerzen, 2017) and new parings continue to evolve (Guest, 2011).

\section{RESEARCH METHODOLOGY}

\section{Data collection}

The study adopted a survey with the use of appropriate literature. With the assistance of three experienced researchers in the study's area, a twelve-category survey questionnaire was initially developed and then pilot tested among twenty top and middle managers and twenty SME staff in the four SMEs in two geographic regions in the UK to enhance the study's qualitative nature. The companies operate in Lincolnshire and Nottinghamshire areas, UK. Anonymity was waived and guaranteed by all the participants and their organisations. By using the results of the pilot, the question categories were subsequently narrowed down to ten. All the administered questionnaire categories are compliant with and mirror similar issues identified and explored in the literature.

For the purposes of data collection the author conducted an empirical survey in order to examine the way the SMEs dealt with their respective challenges especially in relation to how staff contributions towards the implementation of the new products and services were managed to see what impacts there might be. To further improve the validity and reliability of the qualitative materials collected, a cross-section of both management and non-management staff were included in the sample and interviewed using the same semi-structured format. Additionally, to heighten the data validity and response rates on how the challenges of product and service quality were tackled and the emerging impacts faced (Todnem By, 2005), it was thought prudent to host and apply a face-to-face survey in the premises of the companies instead of making recourse to other methods (e.g. telephone interview or online). 
Two sets of semi-structured interview rounds were held with a total of eighty-five staff between 2004/2005 and 2011(68 initially, 17 afterwards).

\section{Questionnaire Survey and Analysis process}

All the ten questionnaire category types were equally administered to each of the eighty-five willing participants. Likewise, all business sections/departments were equally represented by carrying out a targeted, purposeful sampling that focused on each of the SMEs' strategic business units (SBUs), again as a conscious effort to increase the study's qualitative findings. The survey population is hereby defined as four SMEs in two major geographic and administrative counties in the UK. The survey required a two-step procedure, using local company knowledge and expertise: firstly, the identification and secondly, a selection of staff and companies which share similar aspects of those that have been challenged to implement and deal with the issues emanating from product and service delivery especially in changing environments with potential paradoxes (Smith and Lewis, 2011) as reflected in Table 1 below, which gives us a precis of the contextual data neglected in 'mirroring' and 'misting' studies:

Table 1: Organisations, interviewed roles and respondent numbers

\begin{tabular}{|l|l|l|}
\hline Organisations & Role categories & Total respondents \\
\hline $\begin{array}{l}\text { Bakkavor-Laurens } \\
\text { Patisserie }\end{array}$ & Employees & 10 employees, 7 managers $=17$ in \\
& Managers & $\begin{array}{l}2004 / 05 \\
2 \text { employees, } 3 \text { managers=5 in } \\
2011\end{array}$ \\
& & 10 employees, 7 managers $=17$ in \\
Lagat & Employees & $2004 / 05$ \\
& Managers & 2 employees, 2 managers $=4$ in \\
& & 2011 \\
& & \\
\hline Longhurst Housing & Employees & 10 employees, 7 managers $=17$ in \\
& Managers & $2004 / 05$ \\
& & 2 employees, 2 managers $=4$ in \\
\hline
\end{tabular}




\begin{tabular}{|l|l|l|}
\hline Eden Housing & Employees & 10 employees, 7 managers $=17$ in \\
& Managers & $\begin{array}{l}2004 / 05 \\
2 \text { employees, } 2 \text { managers }=4 \text { in } \\
2011\end{array}$ \\
& & \\
\hline
\end{tabular}

Each of the participating staff was randomly chosen to heighten the data validity and reliability issues and they were all successfully interviewed within the timeframe identified. Their responses have been transcribed, checked with each of the participants and these provided the bases for the analysis, discussions and drawing of conclusions. Those aspects that are not reported here have been used in other appropriate fora.

Interviews took approximately one hour and each session was started with the question 'what types of challenges happened in your company and your department and how did you, other colleagues and your company deal with these?' Each of the participants was informed that they could provide further details on their responses to shed further light on the nature of the experiences. The nature of the challenges faced were as follows. With an increasing customer base, Longhurst Housing Association was being tasked by the UK regulators to a) improve the volume and quality of its housing facilities and $b$ ) to ascertain whether staff performance was in line with the complex challenges and c) modernise their services in line with demands. Bakkavor-Laurens Patisserie, which is the largest UK-based cake manufacturer, was acquired by the international Bakkavor Group in Iceland. They had to work extra hard to deal with challenges associated with a) integrating different ethnicities, b) local supermarkets demanding nutrition labelling on cakes and c) boosting their financial returns. They started to focus on growth and expansion of product range. From a hundred and fifty disabled people, Eden Supported Housing came under pressure from the Care Quality Commission a) to provide affordable and quality care, b) from its owners to maximise profits and c) boost performance also started expanding its health and social care services to other parts of the two counties/geographic regions. Lagat came under pressure to by government to a) publicly increase the uptake of educational services b) forced to cut staff numbers as a result of c) under funding provide more of their educational and career counselling services to an increasing number of college-going students in the face of acute competition from more established providers in the market. Each of these types of challenges fitted the theoretical descriptions and therefore warranted closer attention (Kjaerbeck, 2017; Sanders et al., 2014). 
The assistance of three researchers was sought so as to independently review, interpret, axially-code and then thematise the data's findings into respective themes/categories, following Alvesson and Skoldberg (2000) and in conformity with qualitative study. The results are summarised in Table 2. Three stages were involved. The first is a series of steps that describe how each company responded to the strategic challenges. The second is an analysis of a series of themes that refer to people's intended (and the revealed) objectives in each of the steps. The third is a combination of the series of individual and organisational objectives derived from putting together the two previous descriptive and analytic accounts.

\section{Empirical data's results}

The responses of the interviewees highlight the way their organisations emphasised their higher-level objectives and mechanisms, structural couplings and procedures similar to mirroring techniques. The activities were generally noted by staff to primarily deal with short and fixed-term organisational gains (for example, increasing performance, product or service quality and maximising of profits dependent per organisation). Staff started to work round the organisational structures and techniques in the following ways. Firstly, they showed another way of dealing with the systems-wide problems, secondly, they started to identify which of their colleagues they could work more effectively with and thirdly, they started to develop sub-cultural orientations and cliques.

The details of the study's results appeared to have come out of the bolt both in terms of what was found and its contribution - although misting, mirroring and organisation theory appear to indicate that might not be radical. A number of issues have been highlighted below to show what was found from the interviews. The staff responses generally indicated their lack of trust in their senior managers' capability and competence in measuring up to the scale of and delivering the change required. Managers started to show that they particularly depended on using staff's characteristics as if these belonged to management or the companies. In essence, staff were being viewed and their treatment suggested they were considered company properties (see mirroring theory). Other aspects of the data revealed the way managers began monitoring, evaluating and appraising staff performance in ways that staff felt became more intensified rather than engaging in any form of product or service development - as highlighted in mirroring and structuration theory. Those staff whose

performance levels did not mirror the scale of the challenges faced were subjected to 
disciplinary regimes, thereby highlighting a departure from principles of mirroring theory and a breakdown of the structural flow within structuration theory.

Responses provided hereafter showed what was contributed by management and nonmanagement to products and service changes and the impacts of the activities on people, product, services and cultural processes. In 2011 a Bakkavor staff member said 'we... start taking disciplinary action on employees who don't want to change; these are minimum wage jobs and we are being asked too much'. Clearly this staff member failed to see why pressure was being applied on them by management. A manager at Eden stated the following in 2004/05 'there is a lot of work on disciplinary issues...' Although the same individual also highlighted the concurrent use of 'staff training and support' staff interviewed did not share the same optimistic opinion. In 2011 at Longhurst, a top member of management cadre stated the need for staff to be 'very disciplined' and the importance of 'having the plan' (i.e. to discipline staff) 'and revisit it...' Although it was evident from notice-board posters and announcements that fora such as 'focus groups' were being encouraged by management as 'seeds to germinate' the time required for this was considered not to be in management's favour. A similar situation at Lagat necessitated one business unit manager to highlight in 2004/05 the need for 'regular communication and operations meetings' once they have collectively recognised the urgent demands 'to rectify communication blockage...' In 2011, one senior management team member noted the way they were having to carry out dual responsibilities in that company as 'Internal Verifiers for various courses and...employers.' Lagat and Bakkarvor appeared to have an appetite for disciplining staff considered as wayward as they way of tackling the challenges.

The changes took time whilst customers' complaints on the nature of the products and services received grew in their intensity. The constant reminders via management supervisions and notice boards for staff to increase their contributions and quality of their performance did not help an already pressurised environment. The 'breakdown of communication' re-echoed at Longhurst typified the extent to which interactions between hierarchical structures had degenerated to. This further impacted on staff morale and heightened their frustration, anxiety and stress levels as they perceived that their contributions did not matter in managers' perception. Counter-measures were shown in staff who started sub-cultural channels of information sharing and dissemination to counteract the actions of their seniors. One of the middle managers at Lagat stated in 2011 that they started 
to impose tasks and additional responsibilities on other staff with limited support of where they could access the necessary resources. As a result staff started to identify work they could show what they could contribute as a Bakkavor staff member said in 2004/05 they wanted more 'responsibility' in the 'higher roles'. They yearned to be 'more collaborative' as their treatment highlighted management mis-demeanours, which they tried to deal with by 'dipping into other people's roles' at Longhurst thereby going 'beyond their job descriptions'.

\section{ANALYSIS and CONTRIBUTION}

The techniques used by management appear to highlight that the SMEs had to innovate their products and services, often by adopting 'mirroring' so as to fit their products with their governance structures. This is similar to the recommendations by Simon (1962) and MacCormack, Baldwin and Rusnak (2012). The downside of this structural or technical view is that complex organisational problems related to change highlight that not all contexts are the same (Chandler, 1977). In adopting such a strategy, organisations only end up producing photo-types of 'product design organisations' (Colfer and Baldwin, 2016) or if one wills prototypes of an organisation's identity despite different cultural orientations (Hofstede, 2001). It is also assumed that management plays a role in 'mirroring' the organisation's objectives (for example, HRM practices of selection, reward and remuneration and staff discipline procedures) even if the 'techniques' used are 'narrowly' applied (Porter and Kramer, 2011) and do not fit according to stakeholders' perspectives.

To see what contribution mirroring techniques have had on emerging architectural pairings and their limitations, a couple of examples have been selected from research. Porter and Kramer identified how Intel and IBM identified ways that were envisaged to help develop digital capabilities to make some savings on energy utilisation. Wells Fargo also developed a stream of mechanisms and products that were geared at helping their customers to manage a range of difficulties associated with debt and credit. Water-health International harnessed the use of innovative techniques for the purification and distribution of clean water to help the rural and deprived communities in Ghana, the Philippines and India. A distribution system was devised by Hindustan Unilever to help poor female entrepreneurs in rural parts of India. These activities were thought to have received a boost once health and safety and wellbeing training and development schemes were introduced. 
A couple of things are worth noting in relation to the paper's theoretical frame. Firstly, while each highlights what a group of people or organisations chose to do to deal with similar challenges, the required changes were implemented by people at the individual or lowerlevel. What this shows is that the required and anticipated innovations needed a drastic change in people's perspective and behaviour despite the emphasis on what management ought to do. This entailed some level of people 'mirroring' their current objectives and behaviours in line with future behaviours and activities. However, for the new product or service to succeed as a social reality (Berger and Luckmann, 1967), individuals were expected to be loosely coupled or 'misted' with their 'old' organisational architectures (Furlan et al., 2014). Secondly, the examples highlight that organisations are in a state of limbo as to whether they should use 'mirroring' or 'misting' techniques when they attempt to innovate their products, services and introduce change practices. 'Misting' might not be optimal for members especially when structural uncertainty prolongs thereby producing suboptimal performance, sub-standard efficiency and additional ambiguity in organisational forms, role types, structures and cultures. This implies that the positive developments that were proposed in Simon's (1962), Conway's (1968) and Colfer and Baldwin's (2016), 'mirroring hypothesis' were an illusion for the four SMEs that already lacked the requisite resources to do so (Steinerowska-Streb and Steiner, 2014). There appeared to be a blurring between what the types of activities the SMEs were trying to implement using mirroring techniques and what the staff thought should be given priority in unstable environments.

However, the classical 'mirroring' concept (i.e. as part of organisational theory) was not originally designed by its theoretical architects such as MacCormack, Baldwin and Rusnak (2012) to help people realise their individual preferences and capacities. It was designed to help organisations deal with the myriad of complex and unstable problems that had the potential of rendering them obsolete (i.e. 'wicked problem' - see Rittel and Weber, 1973). In this way, it goes against the founding basis of facilitating innovation and acquiring knowledge, i.e. identifying an activity to be performed (via product or service improvement) as a resource via which they may choose to 'mirror' theirs and the organisation's objective (see Baldwin and Clark, 2000). If this happens, some 'misting' of what the organisation had intended to achieve becomes sub-optimal to what the individual members wish to realise as their objective. The 'mirroring' concept was not designed to and therefore does not support individuals who could develop their capacities by 'misting' their organisation's objectives in environments that call for contingent behaviours in order to adapt. The concept of 
'Contingent Misting' was developed when a critique of mirroring techniques was found to have fallen short of reflecting SME members' objectives in the here and now (i.e. contingently) in order to project their objectives with those of their organisations (i.e. misting) to resolve the environmental challenges. One of the constructs' key characteristics is competence which recognises its inclusion onto 'mirroring' and 'misting' at the lower level of individuals. It also shows how people in SMEs a) develop a capacity to choose any number of personal objective(s) as they become contextually-savvy in b) identifying what resources are available to them and their organisation as they engage with c) their organisations' mechanisms.

Alternatively put, when one applies the 'mirroring' concept, they do so at the risk of not allowing individuals to identify resources needed when one uses the structural aspects of mirroring. 'Contingent misting' highlights that it is no longer at the behest of organisations to determine and prioritise the activities that ought to be 'photocopied' onto products and services to achieve objectives. Although 'misting' recognises individual change actors with some level of responsibility (Bouckenooghe, 2010) accorded via some loose-coupling (Furlan et al., 2014) it does not specifically highlight individual competence. What organisational theory in general and strategic change in particular require is something rather special to add to MacCormack, Baldwin and Rusnak's (2012) work therefore: a concept that highlights what SMEs have been missing in their 'organisations' products design' as well as the personal objectives of its members when they both attempt to resolve complex problems. 'Contingent Misting' recognises the need to include people and their objectives as part of an organisation's resources when 'mirroring' is used to resolve product and service-problemrelated issues and what individual and organisational characteristics are required for high quality outcomes. The construct was derived from a critical exploration of the 'mirroring' concept that was morphed into the 'misting' concept, having critically identified the limitations of the former's elements in resolving SMEs' challenges. The process undertaken is similar to the scientific approach, i.e. help initiate observations of phenomena in which people and organisations' objectives and resources are observable and their linkages critiqued and compared with the purpose of developing knowledge.

Given that applying the aspects of the 'mirroring' concept only leads to knowledge that an organisation may use for its own strategic objective in the tradition of Baldwin and Clark (2000) and therefore does not support a process via which individuals have the space and 
time to identify their objectives, mechanisms and capabilities, it is imperative for one to begin searching somewhere different for a new set of ideas to develop individual capacity/competence. Something similar has been attempted as a source of inspiration (Mendy, 2017).

\section{Process of developing 'Contingent Misting'}

To help highlight the paper's theoretical contribution and help deepen our understanding of how to deal with similar systems' wide problems, it was found helpful to organise the study's results by showing the process involved. In Table 2 an interpretation of each of the steps involved is tabularised in the form of six distinct themes from the qualitative interviews: 1) new organisational structures 2) setting up innovative, aligned organisational practices, 3) monitoring and evaluating job performance, 4) building collegial, strategic partnerships, 5) designing new tasks and responsibilities and 6) identifying competence as a contingent strategic capacity. The last category (theme 6) is especially crucial for this study. It identifies and highlights a key resource that management were missing at they tried to 'mirror' their product and service designs to performance outcomes. What employees seemed capable of doing was initiating the development of intentions as a vital ingredient to add to 'mirroring' and 'misting' theories' emphasis on management and organisational structures. The activities involved were found to be short of what SMEs (at the higher level) and individuals (at the lower level) needed to survive their challenges. What staff chose to focus on as their personal observations on various problem-solving capabilities were included in developing 'Contingent Misting' as an attempt to acquire knowledge via the application of the 'mirroring' techniques risked repeating the limitations noted from previous studies.

The paper's contribution highlighted individuals' and SMEs' characteristics/aspects and areas they chose to focus on in turning their organisations' structures, techniques and procedures when these have been identified as failing to address the objectives required in the new ventures. People turned the negative aspects of their managers' actions as they attempted macro-organisation-wide strategies to resolve the systemic challenges into their own development ventures. The staff were not afraid to try new things out having noted the failure of their management to effectively and efficiently apply the mirroring techniques. They tried their actions, activities and intentions as a set of new organisation-wide alternatives to help resolve complex systems plights. 
Table 2. Summary of Study's Results \& 6 interpretive themes

\begin{tabular}{|c|c|c|}
\hline Data's 6 steps & $\begin{array}{l}\text { Organisational and } \\
\text { Members' Aspects }\end{array}$ & 6 themes \\
\hline 1 & $\begin{array}{l}\text { All } 4 \text { organisations realised } \\
\text { they had to adapt to complex } \\
\text { challenges. Managers started } \\
\text { initiating job segmentation } \\
\text { and new objectives. }\end{array}$ & $\begin{array}{l}\text { Emergence of new } \\
\text { organisational structures }\end{array}$ \\
\hline 2 & $\begin{array}{l}\text { New discipline and } \\
\text { grievance procedures are } \\
\text { introduced. }\end{array}$ & $\begin{array}{l}\text { Establishing new } \\
\text { organisational practices to } \\
\text { align people to jobs }\end{array}$ \\
\hline 3 & $\begin{array}{l}\text { New organisational } \\
\text { mechanisms included } \\
\text { evaluation and job } \\
\text { monitoring and performance } \\
\text { evaluation. }\end{array}$ & $\begin{array}{l}\text { Monitoring and evaluating } \\
\text { staff's job performance }\end{array}$ \\
\hline 4 & $\begin{array}{l}\text { Staff started partnering with } \\
\text { others across job sites and } \\
\text { teams. Company bosses } \\
\text { intensified monitoring } \\
\text { techniques. }\end{array}$ & $\begin{array}{l}\text { Building collegial } \\
\text { partnerships }\end{array}$ \\
\hline 5 & $\begin{array}{l}\text { Staff went underground and } \\
\text { independently started to } \\
\text { design jobs/tasks } \\
\text { unbeknown to their bosses. }\end{array}$ & Staff design new tasks \\
\hline 6 & $\begin{array}{l}\text { Staff became more } \\
\text { competent in the new task } \\
\text { dispensation to deal with the } \\
\text { emerging contingencies. }\end{array}$ & $\begin{array}{l}\text { Staff competence is } \\
\text { enhanced as a strategic, } \\
\text { adaptation capacity }\end{array}$ \\
\hline
\end{tabular}

The results of the analysis are an addition to 'mirroring', 'misting' and organisational theory although it should be pointed out that the data might be open to other potential interpretations. It is possible to discover new structures, new mechanisms, new procedures, new objectives and evaluation techniques that might be applied. What the results show are the different characteristics staff and managers individually and collectively developed to cope with the pressures brought about from applying the mirroring technique recommended by MacCormack, Baldwin and Rusnak (2012) and their colleagues. SME staff identified and 
attempted to implement the required adaptations given the contextual constraints. The results of the study are therefore relevant to the seminal works of Simon (1962), Thompson (1967), Conway (1968), Porter and Kramer (2011) and to the research question.

However, applying 'mirroring' techniques to the four SMEs' values, systems, monitoring and evaluation practices were found not to have delivered the tasks effectively and efficiently (Conway's Law, 1968) or to have enhanced value creation according to Porter and Kramer. However, the strategic architectural pairings envisaged from 'mirroring' were found to be limiting (based on the empirical findings) therefore leading one to ascertain that its fundamentals could benefit from some contribution. If one wills, something new is required especially given that mechanisms, structures and procedures were not addressing the contingent problems faced by the four SMEs whose robustness and agility to adapt were called to question having applied the mirroring techniques recommended by Baldwin and Clark, 2000). Furlan et al.'s (2014) 'misting' of organisational structures was found to fall short of recommending contingency (re)adaptation as the paper's theoretical contribution has highlighted. 'Contingent Misting' highlights members' good intentions (Mendy, 2017) as well as an appreciation of SMEs' context, their members' cultural orientations, personal preferences and the extent to which they wish to be loosely or tightly coupled with their firms. This paper's contribution was developed from six steps that seem equivalent to a systematic process.

The new construct looks credible. To verify this, the author compares it with others from the literature (Table 3). Given the existence of previous others (Kjaerbeck, 2017) the author has selected two seminal works in line with the emerging debates and discussions on mirroring and misting. The first is Kotter's (2008) 8-stept model. It has been argued to help organisations implement new structures, partnerships, evaluation and communication procedures which might help in achieving the objectives of the mirroring techniques (MacDuffie, 2013; Baldwin and Clark, 2000). The comparison attempted here should help identify what the approach of developing competence adds and therefore what Kotter's approach appears to be missing. Lewin (1947) also missed such an opportunity earlier. What is analysed as missing is the process via which quality enhancement is created, i.e. the comparison of the linkages between individual and organisational preferences. 
Such testing has not been built into Kotter's work or even Conway's (1968) Law or event in MacCormack, Baldwin and Rusnak's (2012) and hence provides us with an answer to what type of new architectural pairing(s) is/are required: the new construct does not disallow staff to modify aspects of old organisational structures as they adapt tasks to fit into emerging architectures and new ways of interacting. The second major piece of work to compare the author's theoretical contribution is taken from Porter and Kramer (2011). Given their failure to recognise the need for developing an alternative theoretical contribution, it is safe to ascertain from Crane et al. (2014) that one is sorely needed. It is intended to help realise social purposes by recognising organisational mechanisms, procedures, techniques and opportunities for the original parent companies. What is missing is a way of identifying quality enhancement. The earlier examples seem to highlight that as long as parent organisations achieve financial profitability, all manners of mirroring techniques are justifiable. This suggests that the construct that highlights staff's competence is to be preferred over the two constructs included in the table hereunder: it includes a process of quality enhancement whereas the others (including Baldwin and Clark's (2000) and Colfer and Baldwin (2016) do not.

Table 3. Comparison of Kotter's, Porter and Kramer's Model and Contingent Misting

\begin{tabular}{|c|c|c|c|}
\hline $\begin{array}{l}\text { Step } \\
\text { s }\end{array}$ & Kotter's 8 Steps & $\begin{array}{l}\text { Porter and Kramer's } \\
\text { SV }\end{array}$ & Contingent Misting \\
\hline 1 & $\begin{array}{l}\text { Create a sense of urgency } \\
\text { - remove current } \\
\text { constraints }\end{array}$ & $\begin{array}{l}\text { Recognise untapped } \\
\text { human potential }\end{array}$ & $\begin{array}{l}\text { Identify structures and } \\
\text { activities via which } \\
\text { competence is developed }\end{array}$ \\
\hline 2 & $\begin{array}{l}\text { Build a coalition - } \\
\text { experiment with } \\
\text { individuals to guide new } \\
\text { values }\end{array}$ & $\begin{array}{l}\text { Support the } \\
\text { development of } \\
\text { organisational structures }\end{array}$ & $\begin{array}{l}\text { Identify structural and } \\
\text { processual linkages } \\
\text { between personal and } \\
\text { organisational preferences }\end{array}$ \\
\hline 3 & $\begin{array}{l}\text { Form a strategic vision } \\
\text { with new initiatives }\end{array}$ & $\begin{array}{l}\text { Identify a strong } \\
\text { leadership team to guide } \\
\text { vision }\end{array}$ & . \\
\hline 4 & Enlist a volunteer army & & \\
\hline 5 & $\begin{array}{l}\text { Enable action by } \\
\text { removing additional } \\
\text { constraints }\end{array}$ & & $\begin{array}{l}\text { Compare linkages to } \\
\text { establish which has the } \\
\text { highest quality, i.e. is most } \\
\text { effective in increasing }\end{array}$ \\
\hline
\end{tabular}




\begin{tabular}{|l|l|l|l|}
\hline & & & expertise. \\
\hline $\mathbf{6}$ & Generate short-term wins & & $\begin{array}{l}\text { Compare linkages between } \\
\text { the preferences and the } \\
\text { mechanisms to identify } \\
\text { linkages with higher } \\
\text { quality }\end{array}$ \\
\hline $\mathbf{7}$ & Sustain acceleration & $\begin{array}{l}\text { Identify most efficient and } \\
\text { effective processes in } \\
\text { developing and }\end{array}$ \\
\hline $\mathbf{8}$ & $\begin{array}{l}\text { Institute change }- \text { stabilise } \\
\text { change by making } \\
\text { organisational initiatives } \\
\text { stick }\end{array}$ & $\begin{array}{l}\text { Initiate procedures for } \\
\text { new production } \\
\text { processes }\end{array}$ & $\begin{array}{l}\text { Repeat the previous steps } \\
\text { to increase members' and } \\
\text { organisations' coping } \\
\text { capacity }\end{array}$ \\
\hline & & & \\
\hline
\end{tabular}

\section{DISCUSSIONS}

In the previous section, the theoretical contribution of 'Contingent Misting' has been presented and compared against other models and theories. This section highlights additional contributions of 'Contingent Misting' which are in relation to its quality and practical application. Previous studies such as Simon's (1962) and MacDuffie's (2013) have either identified 'mirroring' as a technique or some law (Conway, 1968) that might help effectively map an organisation's structures to new product designs (Gokpinar et al., 2007) but not in terms of their implementation. Given this obvious gap, it was found necessary to include a process that checks the comparability of the linkages between previous constructs and the one being proposed to determine quality. Previous calls to do so (see Lewin, 1947; Kotter, 2008) have not produced what has been done in Table 3 - i.e. the various aspects and stages of 'Contingent Misting'.

In order to determine its usefulness, organisations need to distinguish strategic business units (SBUs) that could benefit from some form of staff development given the nature of their higher-level challenges (see earlier selected examples especially the Wells Fargo one). The fact that customers were using its products to enhance their capacity to manage finance signalled that Wells Fargo's staff had fewer customer complaints to deal with. This then called for the need for individuals (including management) and their company to focus their efforts in developing initiatives for innovative products and services as recommended by 
MacCormack, Baldwin and Rusnak (2012). The six steps shown in Table 3 highlight a theoretical contribution and a way of identifying the types of organisational activities that staff could optimally mirror if they are to effectively and efficiently deal with the complex problems that MacCormack, Baldwin and Rusnak (2012) identified but could not effectively resolve. Previous studies by Simon (1962) and his followers also did not recognise the temporality or contingency of time and space or the importance that personal preferences can play when organisations try to mirror their objectives onto current or future products and services. 'Contingent Misting' contributes in this direction (see stages 2, 6 and 8).

The theoretical contribution also shows how companies can use it as an additional strategic tool (i.e. in addition to 'mirroring' and 'misting') but to do so recognising its contingent nature. Additionally, the six steps that led to producing the construct of 'Contingent Misting' should be viewed as developing some knowledge of linking individual and organisational preferences in a number of activities that previous studies on the topic have missed to focus on - i.e. how to develop staff capacity to deal with complex issues as identified. The outcome recognises not only the structures and activities needed in organisational products designs/architectures (see Puranam et al., 2012) but also a company's and individuals' values, its image and identity. Earlier attempts by Hofstede (2001) failed to recognise the contribution and impact that individual and organisational culture could have on products and service redesign. 'Contingent Misting' recognises that a company's culture (i.e. those projected by its management) can impact and be impacted upon by individuals' values especially when challenged by the urgent need to change. This entailed observing which activities need to be selected based on levels of priority and effectiveness (Gokpinar et al., 2007). The extent to which these could be matched to organisational values and more importantly to harness people's contributions (i.e. via what contingencies) has not been featured in the seminal pieces by Simon (1962) and those thereafter.

'Contingent Misting' contributes special characteristics to previous attempts by Kotter (2008) and Lewin (1947) but latterly by MacDuffie's (2013), Crane et al.'s (2014) and Colfer and Baldwin's (2016) in terms of efficiency-enhancement techniques. Although such techniques, it is claimed, were part of the original intentions of Simon (1962), Thomson (1967) and Conway (1968) in 'mirroring', critically examining the literature, the research examples and the qualitative, empirical data highlight that mirroring techniques could benefit from a construct that serves both as a theoretical contribution and a way to help identify the 
characteristics, the activities, the values and the personal objectives and intentions that people and organisations bring to product and service redesigns. Simply focusing on developing technical expertise is not enough to realise higher-level strategic objectives. A theoretical construct that helps to identify individuals' ability to adapt competently is crucial in dealing with organisation-wide complex challenges as identified and discussed in the case study.

\section{CONCLUSION and FUTURE RESEARCH DIRECTION}

This paper received its inspiration from a number of sources, including the seminal work of Simon (1962) and those subsequently (see Colfer and Baldwin, 2016). Polarising as the debates on architectural pairings and organisational and product/service design are (see Porter and Kramer, 2011), they provided the basis for the study's research question to see whether there is a theoretical contribution to fill the strategy literature gap on mirroring. This led to an analysis of the various aspects of key constructs such as 'mirroring' and 'misting' as a management techniques for implementing strategic change. It was found that the recommended 'mirroring' and 'misting' techniques and strategies received limited attention in SME studies. Such neglect has highlighted the complexity of the problems faced by a range of companies thereby warranting scholars like Furlan et al., (2014) to propose organisationally loosely coupled structures so as to develop a more effective way of dealing with adaptation structures and systems. However, this recent perspective seems to suggest that only business organisations have the solutions to strategy problems but this study has found a new theoretical construct referred to as 'Contingent Misting'. The research question has therefore been answered.

Whilst 'mirroring' enthusiasts seek a tight coupling between organisational structures and products and services, 'misting' scholars claim the opposite. In attempts to demystify whether companies should adopt one or the other's techniques and thereby become more effective, the paper set out to demystify the apparent ambiguity between the two major constructs. It did so by analysing what each of the propositions had to offer and using empirical data from semistructured interviewees. This was needed to clarify what each proposal was recommending organisations to do, secondly whether the good intentions in both techniques was achievable and more importantly, whether a new construct could emerge. The analysis found that different types of organisational activities and structures are necessary to be able to implement the recommendations from both techniques. The results of the empirical data 
found that SMEs need to adopt a more contingent approach should they wish to implement 'mirroring' or 'misting' techniques especially when they are challenged to (re)adapt their products and services to a range of external demands. At the same time, companies should also allow some space and time for staff to make their preferences felt within the new structures, processes and systems. This led to the development of the 'Contingent Misting' construct whose characteristic are considered necessary to help companies identify which activities, structures and processes are needed in order to achieve greater efficacy and efficiency when they launch new products and services. The new construct highlights the pivotal role people play in developing the required coping capacity.

The paper's theoretical contribution was analytically compared to other, previous attempts and its benefits highlights its timely introduction in the literature (Kotter, 2008; Lewin, 1947; Thompson (1967); Simon, 1962; MacDuffie, 2013). Its basis is developed from the reactions of staff to four organisations that were faced with life-threatening, complex challenges in the here and now. The results show the need for Business and HRM strategists to develop people's competence if they wish to save their companies from similar life-threatening adaptation challenges. It is noted that those implementing 'Contingent Misting' should pay close attention to people, activities, structures as well as intentions/objectives and checking for their linkages to ensure that high quality outcomes are achievable. One of the new construct's special attribute and something that Strategic Change in particular needs to include within the 'mirroring' and 'misting' debates and discussions triggered by and Orton and Weick (1990), Brusoni et al., (2001), MacCormack, Baldwin and Rusnak (2012) is what people have identified as important life-saving activities and preferences. People's expectations and objectives and activities that reflect these should be added to standard, management 'mirroring' techniques so as to increase their possibility of achieving the type of successful 'organisation design products' envisaged earlier by Conway (1968). These aspects have been crucially lacking in the classical works of Simon (1962) and colleagues. Therefore people and preferences are proposed as new, additional characteristics within organisations' architectural, structural and product pairings. The extent to which these shape strategic change design and implementation processes provide a signal for future research directions. 


\section{References}

Alexander, C. (1964). Notes on the Synthesis of Form. Harvard University Press: Cambridge, MA.

Alvesson, M. and Skoldberg, K. (2000). Reflexive methodology: New vistas for qualitative research. London: Sage.

Baldwin, C. Y. and Clark, K. B. (2000). Design rules: The power of modularity (Vol. 1). MIT Press.

Becker, B. E. and Huselid, M. A. (2006). Strategic human resources management: where do we go from here? Journal of Management, 32(6), 898-925.

Berger, P. L. and Luckmann, T. (1967). The social construction of reality: A treatise in the sociology of knowledge. Anchor: New York, NY.

Boukenooghe, D. (2010). Positioning Change Recipients' Attitudes toward Change in the Organizational Change Literature. The Journal of Applied Behavioural Science, 46(4), 500-531.

Brewster, C. (1999). 'Different paradigms in strategic HRM: Questions raised by comparative research'. In P. Wright, L. Dyer, L. Boudreau and G. Milkovich (Eds.) Research in personnel and human resource management: Strategic HRM in the 21st century (Supplement 4, 213-238). Greenwich, CT: JAI Press.

Brusoni, S. and Prencipe, A. (2001). Unpacking the black box of modularity: technologies, products and organizations. Industrial and Corporate Change, 10(1), 179-205.

Budhwar, P., Tung, R. L., Varma, A. and Do, H. (2017). Developments in Human Resource Management in MNCs from BRICS Nations: A Review and Future Research Agenda. Journal of International Management, 23, 111-123.

Chandler, A. D. (1977). The Visible Hand: The Managerial Revolution in American Business. Harvard University Press: Cambridge, MA.

Chesbrough, H. (2003). The logic of open innovation: managing intellectual property. California Management Review, 33-58.

Colfer, L. J. and Baldwin, C. Y. (2016). The mirroring hypothesis: theory, evidence, and exceptions. Industrial and Corporate Change, 25(5), 709-738.

Conway, M. (1968). How do committees invent? Datamation, 14(4), 28-31.

Crane, A., Palazzo, G., Spence, L. J. and Matten, D. (2014). Contesting the value of 'Creating Shared Value'. California Management Review, 56(2), 130-153. 
Crawley, E., de Weck, O., Eppinger, S., Magee, C., Moses, J., Seering, W. and Whitney, D. (2004). System Architecture and Complexity. In Engineering Systems Symposium. Massachusetts Institute of Technology, Cambridge, 80.

Elia, S., Massini, S. and Narula, R. (2017). Disintegration, modularity and entry mode choice: Mirroring technical and organizational architectures in business functions offshoring. Journal of Business Research. December.

Estrin, S., Nielsen, B. B. and Nielsen, S. (2017). Emerging Market Multinational Companies and Internationalization: The Role of Home Country Urbanization. Journal of International Management, 23, 326-339.

Fixson, S. K. and Park, J. K. (2008). The power of integrality: Linkages between product architecture, innovation, and industry structure. Research Policy, 37(8), 1296-1316.

Fleming, L. and Sorenson, O. (2004). Science and the Diffusion of Knowledge. Research Policy, 33(10), 1615-1634.

Furlan, A., Cabigiosu, A. and Camuffo, A. (2014). When the mirror gets misted up: Modularity and technological change. Strategic Management Journal, 35(6), 789-807.

Garezzi, M., Terzi, S., Bertazzi, N. and Brianza, M. (2005). Organisational change and knowledge management in product lifecycle model implementation. International Journal of Product Lifecycle Model, 1(1), 43-51.

Galbraith, J. (1974). Organization design: an information processing view. Interfaces, 4(3), $28-36$.

Gerhart, B. and Fang, M. (2005). National culture and human resource management: assumptions and evidence. International Journal of Human Resource Management, 16(1), 41-52.

Goerzen, A. (2017). Small Firm Boundary-spanning via Bridging Ties: Achieving International Connectivity via Cross-border Inter-cluster Alliances. Journal of International Management, 23, 1-12.

Gokpinar, B., Hopp, W. and Iravani, S. M. (2007). The impact of product architecture and organization structure on efficiency and quality of complex product development. Unpublished work.

Guest, D. (2011). Human Resource Management and Performance: still searching for some answers. Human Resource Management Journal, 21(7), 1092-1106.

Gunasekaran, A., Rai, B. K. and Griffin, M. (2011). Resilience and competitiveness of small and medium size enterprises: an empirical research. International Journal of Production Research, 49(18), 5489-5509. 
Henderson, R. M. and Clark, K. B. (1990). Architectural innovation: The reconfiguration of existing product technologies and the failure of established firms. Administrative Science Quarterly, 9-30.

Hofstede, Geert (2001). Culture's Consequences: comparing values, behaviors, institutions, and organizations across nations (2nd Ed.). CA: Thousand Oaks.

Huselid, M. A., Jackson, S. E. and Schuler, R. S. (1997). Technical and strategic human resource management effectiveness as determinants of firm performance. Academy of Management Journal, 40, 171-188.

Huselid, M. A. (1995). The impact of human resource management practices on turnover, productivity and corporate financial performance. Academy of Management Journal, 38, 635-670.

Ichniowski, C., Shaw, K. and Prennushi, G. (1997). The effects of human resource management practices on productivity: A study of steel finishing lines. American Economic Review, 87, 291-313.

Jimenez, A., Boehe, D. M., Taras, V. and Caprar, D. V. (2017). Working across Boundaries: Current and Future Perspectives on Global Virtual Teams. Journal of International Management, 23, 341-349.

Kaufman, B. E. (2015). Market competition, HRM and firm performance: The conventional paradigm critiqued and reformulated. Human Resource Management Review, 25(1), 107125.

Kjaerbeck, S. (2017). Positioning and change in a hospital ward. Journal of Organizational Change Management, 30(1), 43-53.

Kola, K. and Kadongo, O. (2017). Macroeconomic risks and REITs returns: A comparative analysis. Research in International Business and Finance, 42, 1228-1243.

Kotter, J. P. (2008). A sense of urgency. Harvard Business Review: Harvard.

Langlois, R. N. (2002). Modularity in technology and organization. Journal of Economic Behavior and Organization, 49(1), 19-37.

Lawrence, P. R. and Lorsch, J. W. (1967). Organization and Environment. Harvard Business School Press: Boston, MA.

Lenseges, M. L., Hollensbe, E. C. and Masterson, S. S. (2016). The human side of restructures: The role of shifting identification. Journal of Management Inquiry, 25(4), $382-396$.

Lewin, K. (1947). Frontiers of group dynamics: Concept, method and reality in social science, social equilibria and social change. Human Relations, 1, 5-41. 
Liu, Y. and Vrontis, D. (2017). Emerging-market firms venturing into advanced economies: The role of context. Thunderbird International Business Review, 59, 255-261.

MacDuffie, J. P. (2013). Modularity-as-property, modularization-as-process, and 'modularity'-as-frame: Lessons from product architecture initiatives in the global automotive industry. Global Strategy Journal, 3(1), 8-40.

MacCormack, A., Baldwin, C. and Rusnak, J. (2012). Exploring the duality between product and organizational architectures: A test of the "mirroring" hypothesis. Research Policy, 41(8), 1309-1324.

MacCormack, A., Rusnak, J. and Baldwin, C. (2006). Exploring the structure of complex software designs: an empirical study of open source and proprietary code. Management Science, 52(7), 1015-1030.

McGregor, D. (1960). The Human Side of the Enterprise. Macmillan: New York.

Mendy, J. (2017). 'Key HRM Challenges and Benefits: The Contributions of the HR Scaffolding'. In J. Mendy (Eds.), Teaching Human Resources and Organizational Behavior at the College Level, Pennsylvania: IGI Global, 1 - 57.

Moon, H. C., Parc, J., Yim, S. H. and Park, N. (2011). An extension of Porter and Kramer's 'Creating Shared Value (SV): Reorienting strategies and seeking international cooperation. Journal of International and Area Studies, 18(2), 49-64.

Nickerson, J. A. and Zenger, T. R. (2004). A knowledge-based theory of the firm-the problem-solving perspective. Organization Science, 15(6), 617-632

Nonaka, I. (1994). A dynamic theory of organizational knowledge creation. Organization Science, 5(1), 14-37.

Orton, J. D. and Weick, K. E. (1990). Loosely-coupled systems: a reconceptualization. Academy of Management Review, 15, 203-223.

Pfeffer, J. (1995). Producing sustainable competitive advantage through the effective management of people. Academy of Management Executive, 9, 55-69.

Porter, M. E. and Kramer, M. R. (2011). The big idea: Creating value rethinking capitalism. Harvard Business Review, January-February Issue.

Puranam, P., Raveendran, M. and Knudsen, T. (2012). Organization design: the epistemic interdependence perspective. Academy of Management Review, 37(3), 419-440.

Quaicoe, A., Aboadgy, A. Q. Q. and Bokpin, G. A. (2017). Assessing the impact of export processing zones on economic growth in Ghana. Research in International Business and Finance, 42, 1150-1163. 
Rittel, H. and Webber, M. (1973). Dilemmas in a General Theory of Planning', 4, 155-169, Policy Sciences, Elsevier Scientific Publishing Company, Inc., Amsterdam. In N. Cross (1984 Ed.), Developments in Design Methodology, J. Wiley and Sons: Chichester, 135144.

Sanders, K, Shipton, H, Gomes, JFS (2014). Is the HRM Process Important? Past, Current and Future Challenges. Human Resource Management, 53(4), 489-503.

Sanderson, S., Uzumeri, M. (1995). Managing product families: the case of the Sony Walkman. Research Policy, 24(5), 761-782.

Saridakis, G., Yanqing, L. and Cooper, C. L. (2017). Exploring the relationship between HRM and firm performance: A meta-analysis of longitudinal studies. Human Resource Management Review, 27, 87-96.

Scott, W. R. (1981). Organizations: Rational, Natural and Open Systems. Prentice-Hall: New Jersey.

Simon, H. A. (1962). The architecture of complexity. Proceedings of the American Philosophical Society, 106(6), 467-482.

Smith, W. K. and Lewis, M. W. (2011). Toward a theory of paradox: A dynamic equilibrium model of organizing. Academy of Management Review, 36(2), 381-403.

Sosa, M., Eppinger, S. and Rowles, C. (2004). The misalignment of product architecture and organizational structure in complex product development. Management Science 50, $1674-1689$.

Sosa, M., Eppinger, S. and Rowles, C. (2007). A network approach to define modularity of components in complex products. Transactions of the ASME, 129, 1118-1129.

Steinerowska-Streb, I. and Steiner, A. (2014). An analysis of external finance availability on SMEs' decision making: A case study of the emerging market of Poland. Thunderbird International Business Review, 56, 373-386.

Tassabehji, R. and Isherwoood, A. (2014). Management use of strategic tools for innovating during turbulent times. Strategic Change, 23, 63-80.

Thompson, J. D. (1967). Organizations in Action: Social Science Bases of Administrative Theory. McGraw-Hill: New York.

Todnem By, R (2005). Organisational Change Management: A Critical Review. Journal of Change Management, 5(4), 369-380.

Top, M., Akdere, M. and Turcan, M. (2015). Examining transformational leadership, job satisfaction, organizational commitment and organizational trust in Turkish hospitals: 
Public servants versus private sector employees. International Journal of Human Resource Management, 26, 1259-1282.

Tushman, M. L. and Nadler, D. A. (1978). Information processing as an integrating concept in organizational design. Academy of Management Review, 3(3), 613-624.

Ulrich, K. (1995). The role of product architecture in the manufacturing firm. Research Policy, 24, 419-440 (reprinted in Raghu, G., Kumaraswamy, A., Langlois, R.N. (Eds.), Managing in the Modular Age: Architectures, Networks, and Organizations. Blackwell, Oxford/Malden: MA.

Ulrich, D. and Dulebohn, J. H. (2015). Are we there yet? What's next for HR? Human Resource Management Review, 25(2), 188-204.

Van Wanrooy, B., Bewley, H., Bryson, A., Forth, J., Freeth, S., Stokes, L. and Wood, S. (2013) Employment Relations in the Shadow of Recession: Findings from the 2011 Workplace Employment Relations Study. Palgrave: London.

Weick, K. E. (1976). Educational organizations as loosely coupled systems. Administrative Science Quarterly, 21(1), 1-19.

Williams, N. L., Ridgman, T., Shi, Y. and Ferdinand, N. (2014). Internationalization as interaction: A process perspective on internationalization from a small developing country. Thunderbird International Business Review, 56(2), 127-144.

Wolter, C. and Veloso. F. M. (2008). The effects of innovation on vertical structure: perspectives on transaction costs and competences. Academy of Management Review, $33(3), 586-605$.

Zoogah, D. and Mburu, H. K. (2015). Are firms in developing countries in spider webs or iron cages? Geographic traps and firm performance. Thunderbird International Business Review, 57(6), 481-503. 